\title{
EDITORIAL
}

\section{Ways forward to identify new ACPA targets in RA}

\author{
A Jimmy Ytterberg and Vivianne Malmström* \\ See related research by Raijmakers et al., http://arthritis-research.com/content/14/3/R114
}

\begin{abstract}
Anti-citrullinated protein antibodies (ACPAs) of the IgG subtype have become a critical hallmark of HLAassociated rheumatoid arthritis (RA) and point to important contributions from the adaptive immune system. To dissect the contributing autoimmune reactions, investigators must not only identify the protein targets of ACPA but also define the precise peptides recognized by the immune system. Several possible approaches could be used to achieve this goal, and sensitive mass spectrometry of relevant tissue is a promising way forward in advancing our detailed understanding of autoimmune immune reactions involved in RA pathogenesis.
\end{abstract}

In a recent issue of Arthritis Research \& Therapy, Raijmakers and colleagues [1] use an unbiased approach via mass spectrometry to identify candidate citrullinated peptides that have the potential to be involved in rheumatoid arthritis (RA). By sampling synovial fluid from a number of patients with RA as well as from nonRA disease control subjects, the authors demonstrate that it is possible to broaden the arsenal of potential autoantigenic peptides that deserve further investigation as candidate B- or T-cell epitopes in the setting of anticitrullinated protein antibody (ACPA)-positive RA disease.

Why citrullination, a common physiological protein modification, is regarded as such a threat to the immune system in patients with RA and causes more than $60 \%$ of patients to mount autoantibody titers (ACPA) remains an enigma. One underlying reason is the strong bias toward a certain set of HLA class II alleles that are very capable of presenting this altered amino acid [2,3], but that is not enough. In fact, most individuals carrying the HLA

${ }^{*}$ Correspondence: vivianne.malmstrom@ki.se

Rheumatology Unit, Dept Of Medicine, CMM L8:04, Karolinska University Hospital Solna, Karolinska Institutet, SE-171 76 Stockholm, Sweden shared epitope alleles do not develop RA. Clearly, these autoimmune reactions must be triggered, and here environmental provocations (smoking, bacterial infection in the gum, and so on) have become an intriguing hypothesis (reviewed in [4]).

A central function of citrullination is to contribute to structure (for example, in the skin, hair follicles, central nervous system, and histones). Another, partly related, function is to destabilize proteins and mark them for degradation. In most cases, the regulated step in degradation of proteins is initial cleavage followed by rapid removal of the degradation products. The commonality of ACPAs in patients with RA suggests that citrullinated proteins are readily exposed to the immune system. Indeed, citrullinated proteins are found and even abundant at many sites of inflammation [5]. ACPA targets are probably a mix of degradation products and secreted or cell-bound proteins [6,7]. In their study, Raijmakers and colleagues demonstrate that synovial fluid of patients with RA and, to lesser degree, that of disease control subjects accumulate fibrinogen degradation products and that the peptides thereof are citrullinated (to a small but significant degree).

In the last few years, several studies that present either improved methods for the identification of citrullinated peptides or new citrullinated targets present in biological tissues have been published (reviewed in [8]). Citrullination of arginines can easily be confused with deamidation of asparagine or glutamine, and this potential confusion makes correct assignments of citrullinated peptides very important. The present study illustrates several characteristics that are diagnostic for citrulline species, such as a decrease in the precursor charge state, shifts in retention time when reverse-phase chromatography is used, and changes in the relative abundance of the ions in tandem mass spectrometry. With this approach, citrullinated peptides from a variety of sources $[9,10]$ can be identified and validated.

The next step is to evaluate whether these 'suspects' are indeed involved in immune reactions and, if so, the nature of these responses. Understanding the chronic autoimmune reactions in affected joints may hold critical clues toward ways of reversing them and re-establishing a tolerogenic state. 
An even broader vision of current RA research entails preventive measurements toward disease development. Dissecting disease-initiating events (since ACPAs appear before clinical onset) will require access to different material from subjects at risk of disease. Time will tell what technical platforms will help us dissect ACPA targets in this setting. Clearly, unbiased approaches such as the one described in the present study are very attractive.

\section{Abbreviations}

ACPA, anti-citrullinated protein antibody; RA, rheumatoid arthritis.

\section{Competing interests}

The authors declare that they have no competing interests.

Published: 24 September 2012

\section{References}

1. Raijmakers R, van Beers JJ, El-Azzouny M, Visser NF, Bozic B, Pruijn GJ, Heck AJ: Elevated levels of fibrinogen-derived endogenous citrullinated peptides in synovial fluid of rheumatoid arthritis patients. Arthritis Res Ther 2012, 14:R114.

2. Hill JA, Southwood S, Sette A, Jevnikar AM, Bell DA, Cairns E: Cutting edge: the conversion of arginine to citrulline allows for a high-affinity peptide interaction with the rheumatoid arthritis-associated HLA-DRB1*0401 MHC class II molecule. J Immunol 2003, 171:538-541.

3. Snir O, Rieck M, Gebe JA, Yue BB, Rawlings CA, Nepom G, Malmström V, Buckner JH: Identification and functional characterization of T cells reactive to citrullinated vimentin in $\mathrm{HLA}-\mathrm{DRB} 1{ }^{*} 0401$-positive humanized mice and rheumatoid arthritis patients. Arthritis Rheum 2011, 63:2873-2883.
4. Klareskog L, Malmström V, Lundberg K, Padyukov L, Alfredsson L: Smoking, citrullination and genetic variability in the immunopathogenesis of rheumatoid arthritis. Semin Immunol 2011, 23:92-98.

5. Makrygiannakis D, af Klint E, Lundberg IE, Lofberg R, Ulfgren AK, Klareskog L, Catrina Al: Citrullination is an inflammation-dependent process. Ann Rheum Dis 2006, 65:1219-1222.

6. Bae S, Kim H, Lee N, Won C, KIm HR, Hwang YI, Song YW, Kang JS, Lee WJ: alpha-Enolase expressed on the surfaces of monocytes and macrophages induces robust synovial inflammation in rheumatoid arthritis. J Immunol 2012, 189:365-372.

7. Harre U, Georgess D, Bang H, Bozec A, Axmann R, Ossipova E, Jakobsson PJ, Baum W, Nimmerjahn F, Szarka E, Sarmay G, Krumbholz G, Neumann E, Toes R, Scherer HU, Catrina Al, Klareskog L, Jurdic P, Schett G: Induction of osteoclastogenesis and bone loss by human autoantibodies against citrullinated vimentin. J Clin Invest 2012, 122:1791-1802.

8. De Ceuleneer M, Van Steendam K, Dhaenens M, Deforce D: In vivo relevance of citrullinated proteins and the challenges in their detection. Proteomics 2012, 12:752-760.

9. Hermansson M, Artemenko K, Ossipova E, Eriksson H, Lengqvist J, Makrygiannakis D, Catrina Al, Nicholas AP, Klareskog L, Savitski M, Zubarev RA, Jakobsson PJ: MS analysis of rheumatoid arthritic synovial tissue identifies specific citrullination sites on fibrinogen. Proteomics Clin Appl 2010, 4:511-518.

10. Ytterberg AJ, Reynisdottir G, Ossipova E, Rutishauser D, Hensvold A, Eklund A, Sköld M, Grunewald J, Lundberg K, Malmström V, Jakobsson PJ, Zubarev RA, Klareskog L, Catrina Al: Identification of shared immunological targets in the lungs and joints of patients with rheumatoid arthritis. Ann Rheum Dis 2012, 71:A19.

doi:10.1186/ar4031

Cite this article as: Ytterberg AJ, Malmström $\mathrm{V}$ : Ways forward to identify new ACPA targets in RA. Arthritis Research \& Therapy 2012, 14:124. 